\title{
Evaluation of Equations to Predict Dry Matter Intake of Dairy Heifers
}

\author{
P. C. Hoffman, ${ }^{1}$ K. A. Weigel, and R. M. Wernberg \\ Department of Dairy Science, University of Wisconsin, Madison 53706
}

\begin{abstract}
Daily pen dry matter intakes (DMI, $\mathrm{n}=9,275$ ) were collected over a 28-mo period at the University of Wisconsin's Integrated Dairy Research Facility. Heifers were housed in pens containing 8 Holstein or Holstein $\times$ Jersey crossbred heifers/pen. Heifer diets were formulated to energy and protein requirement twice monthly, with feed intake, dietary nutrient density, and ambient temperature recorded daily. Heifers were weighed at 60-d intervals, and mean pen body weights (BW) were estimated for each day between the weigh dates using the interval average daily gain as a regression coefficient. Prediction of heifer DMI was evaluated using the equations of NRC (2001), Quigley et al. (1986), or alternative random effects mixed models or nonlinear exponential models. The effects of breed, $\mathrm{BW}$, temperature and neutral detergent fiber deviation $(\mathrm{NDFdv})$ were considered as independent variables. Holstein and crossbred heifer DMI was predicted with reasonable precision [standard error $(\mathrm{SE})<0.86 \mathrm{~kg} / \mathrm{d}$ ], by the NRC (2001) or Quigley et al. (1986) equations, but heifer DMI was over- or underpredicted for heifers $>500 \mathrm{~kg}$, respectively. Improved heifer DMI prediction equations were achieved with exponential models. For Holsteins $(\mathrm{SE}=0.71 \mathrm{~kg} / \mathrm{d})$, the prediction equation was: DMI $(\mathrm{kg} / \mathrm{d})=15.79 \times\left[1-\mathrm{e}^{(-0.00210 \times \mathrm{BW})}\right]-0.0820$ $\times \mathrm{NDFdv}$, where NDFdv $=($ dietary neutral detergent fiber as a $\%$ of dry matter $)-\{22.07+[0.08714 \times \mathrm{BW}]$ $\left.-\left[0.00007383 \times(\mathrm{BW})^{2}\right]\right\}$. For crossbred heifers $(\mathrm{SE}=$ $0.60 \mathrm{~kg} / \mathrm{d})$, the prediction equation was: DMI $(\mathrm{kg} / \mathrm{d})=$ $13.48 \times\left[1-\mathrm{e}^{(-0.00271 \times \mathrm{BW})}\right]-0.0824 \times \mathrm{NDFdv}$ where $\mathrm{NDFdv}=($ dietary neutral detergent fiber as a \% of dry matter $)-\{23.11+[0.07968 \times \mathrm{BW}]-[0.00006252 \times$ $\left.\left.(\mathrm{BW})^{2}\right]\right\}$. Alternative exponential DMI model equations when dietary neutral detergent fiber is unknown were also developed. The Holstein DMI equation $(\mathrm{SE}=0.73$ $\mathrm{kg} / \mathrm{d})$ was: DMI $(\mathrm{kg} / \mathrm{d})=15.36 \times\left[1-\mathrm{e}^{(-0.00220 \times \mathrm{BW})}\right]$, and the crossbred DMI equation $(\mathrm{SE}=0.81 \mathrm{~kg} / \mathrm{d})$ was: DMI $(\mathrm{kg} / \mathrm{d})=12.91 \times\left[1-\mathrm{e}^{(-0.00295 \times \mathrm{BW})}\right]$.
\end{abstract}

Received August 27, 2007.

Accepted May 29, 2008.

${ }^{1}$ Corresponding author: pchoffma@facstaff.wisc.edu
Key words: dry matter intake, heifer, intake equation

\section{INTRODUCTION}

Predicting DMI of dairy heifers is an important aspect of dairy heifer nutrition programs, but predicting DMI of dairy heifers has been challenging for several reasons. First, published data of dairy heifer DMI are sparse, and large databases of dairy heifer DMI across a wide range of BW have not been available for study. Second, some published (Quigley et al., 1986) DMI prediction equations for dairy heifers use dietary composition or $\mathrm{ADG}$ as independent variables, and databases containing diet composition and $\mathrm{ADG}$ have not been available to validate these equations. Thus, formal evaluation of the utility of published DMI equations (Quigley et al., 1986; NRC, 2001) to predict dairy heifer DMI has not been conducted. The objective of this project was to evaluate and possibly improve upon the utility of previously published dairy heifer DMI equations, because a large database of DMI for dairy heifers managed in a near-commercial environment became available at the University of Wisconsin's Integrated Dairy Research Facility (IDRF).

\section{MATERIALS AND METHODS}

\section{Heifers and Feed Intake}

Daily pen DMI were collected from the University of Wisconsin's IDRF over a 28 -mo period. Heifers were housed in $4.5 \times 9.0 \mathrm{~m}$ pens with $30 \mathrm{~m}^{2}$ of resting area/ heifer and bedded with sawdust 3 times/wk. Eight heifers, at approximately 4.0 mo of age, were assigned to a pen, and heifers had access to $0.55 \mathrm{~m}$ of bunk space/ heifer. During the 28-mo period, the IDRF facilitated a crossbreeding research trial (Maltecca et al., 2006) in which $50 \%$ of the IDRF lactating dairy cows were mated to Holstein $\times$ Jersey sires, resulting in Holstein $\times$ Jersey backcross heifers (crossbred). The remaining $50 \%$ of the lactating cows and all of the virgin heifers were mated to Holstein sires. As a result, 2 pools of heifers, Holstein and crossbred heifers, were reared at IDRF. Holstein and crossbred heifers were not com- 
mingled but rather assigned to separate pens in groups of 8 . During the 28 -mo period, DMI data were available from 44 pens of Holstein heifers and 30 pens of crossbred heifers.

Daily pen DMI data were collected as a part of a streaming feed management system at the IDRF facility. Forages and grains fed to heifers were sampled twice a month and evaluated for DM by drying at $55^{\circ} \mathrm{C}$ for $48 \mathrm{~h}$. Samples were then milled through a Udy mill (Udy Corp., Boulder, CO) fit with a 1-mm screen and saved for nutrient analysis. Residual DM was determined on $1-\mathrm{mm}$ ground samples by drying at $105^{\circ} \mathrm{C}$ for $3 \mathrm{~h}$. The CP, NDF, NDF-CP, fat, ash, Ca, Mg, K, and $\mathrm{P}$ of forage and grain samples were determined by near-infrared reflectance spectroscopy (Model 6500; FOSS-NIR System, Silver Spring, MD) by the University of Wisconsin Soil and Forage Analysis Laboratory, Marshfield. Lots of protein supplements purchased by IDRF were sample 5 times/lot and determined for the aforementioned nutrients by wet chemistry.

Protein supplements were evaluated for $\mathrm{CP}$ and ash by AOAC (1990) procedures. Crude fat was determined by extraction with petroleum ether after acid treatment (AOAC, 1990). The NDF contents of the protein supplements were determined by the procedures of Goering and Van Soest (1970), with modifications by Mertens (1992). The NDF-CP contents of the protein supplements were ascertained by an initial nonsequential determination of NDF using aforementioned procedures with the exception that no sodium sulfite was used in the NDF procedure to avoid removal of CP from NDF. Determination of $\mathrm{CP}$ in the NDF residues was derived by Kjeldahl procedures (AOAC, 1990). Calcium, K, and $\mathrm{Mg}$ were determined using atomic absorption spectroscopy (GBC Scientific, Gilberts, IL) and P by colorimetric methods (Coleman Instruments Inc., Maywood, IL). The total digestible nutrients (TDN), $\mathrm{ME}, \mathrm{NE}_{\mathrm{G}}$, and $\mathrm{NE}_{\mathrm{M}}$ of forages, grains, and protein supplements fed to heifers, were estimated using summative equations (NRC, 2001).

Immediately after twice-monthly forage and grain analysis were completed, 3 rations were formulated for Holstein heifers weighing $<275,275$ to 450 , and $>450 \mathrm{~kg}$ according to NRC (2001) requirements. Because of location latitude $\left(44^{\circ} \mathrm{N}\right)$, a mbient temperatures vary considerably $\left(-31\right.$ to $\left.35^{\circ} \mathrm{C}\right)$ at the IDRF facility; thus, ambient temperature was used to modify maintenance energy requirements of heifers (NRC, 2001). Diets formulated for Holstein heifers were also fed to crossbred heifers, but different weight criteria $(<250,250$ to $425,>425$ $\mathrm{kg}$ ) were used to account for differences in physiological maturity (NRC, 2001) of the crossbred heifers. Diet ingredients were fed separately to pens of heifers once daily at $0800 \mathrm{~h}$. The DM contents of forages were moni- tored on a weekly basis, and diets were adjusted when forage DM content changed more than 4.0 percentage units. Consumption of heifer diets was monitored daily using a bunk scoring system. Each day, before feeding, at $0630 \mathrm{~h}$, feed bunks were scored and classified as 0 = slick feed bunk-no feed remaining; $1=$ few and scattered feed particles remaining; $2=$ bottom of feed bunk covered in thin layer of feed; or $3=$ large amounts of feed remaining with the bottom of the feed bunk not visible. Orts were not weighed for heifer pens with bunk scores $<2$, because the amount of feed remaining was negligible $(<1.0 \mathrm{~kg})$. Orts were weighed for heifer pens with bunk scores of 2 and 3 with weight of ort subtracted from the daily feed offering. The DM content of the ort was not measured, and the DM content of the diet was used as a surrogate ort DM. The bunk scoring system (0 to 3) was also used to manage daily pen feed allocations to feed heifers as close to exact DMI as possible. This objective was facilitated by systematically feeding heifers to achieve a postfeeding bunk score of 1 at all times. Feed allocations were increased by $2 \%$ on an as-fed basis for a given pen if the postfeeding bunk score was 0 . Likewise, daily feed allocations were decreased by 3 or $8 \%$ on an as-fed basis for pens with postfeeding bunk scores of 2 or 3, respectively. Heifers were weighed at 60-d intervals using a cattle chute (Real Tuff, Clearbrook, MN) fit with an electronic scale (Tru-Test Inc., Mineral Wells, TX). Mean pen BW was estimated each day by adjusting the pen BW for each day between the weigh intervals using the pen-specific interval ADG as a regression coefficient. All animal handling and experimental procedures were approved by the Research Animal Resource Committee at the University of Wisconsin-Madison.

\section{DMI Database}

A database of DM and nutrient intakes was constructed to evaluate the NRC (2001) and Quigley et al. (1986) DMI equations and to explore alternative model equations to predict dairy heifer DMI. Daily as-fed pen feed intakes were combined with dietary DM and nutrient densities, resulting in daily pen estimates of $\mathrm{DM}, \mathrm{CP}, \mathrm{NDF}, \mathrm{TDN}, \mathrm{ME}, \mathrm{NE}_{\mathrm{G}}$, and $\mathrm{NE}_{\mathrm{M}}$ intake. These data were further combined with daily adjusted mean pen BW to express and evaluate DM or nutrient intake as a percentage of BW. Finally, average ambient (high + low) $/ 2$ temperature (T) was added to the database for each data collection day over the 28-mo period to evaluate potential effects of T on DMI.

Heifer DMI was predicted by the NRC (2001) equation: DMI, $\mathrm{kg} / \mathrm{d}=\left[\mathrm{BW}^{0.75}\left(0.2435 \times \mathrm{NE}_{\mathrm{M}}-0.0466 \times\right.\right.$ $\left.\left.\mathrm{NE}_{\mathrm{M}}{ }^{2}-0.1128\right) / \mathrm{NE}_{\mathrm{M}}\right]$. Likewise, heifer DMI was predicted by Quigley et al. (1986): DMI, $\mathrm{kg} / \mathrm{d}=-29.86+$ 
Table 1. Diet composition and intake characteristics by BW of Holstein and crossbred heifers

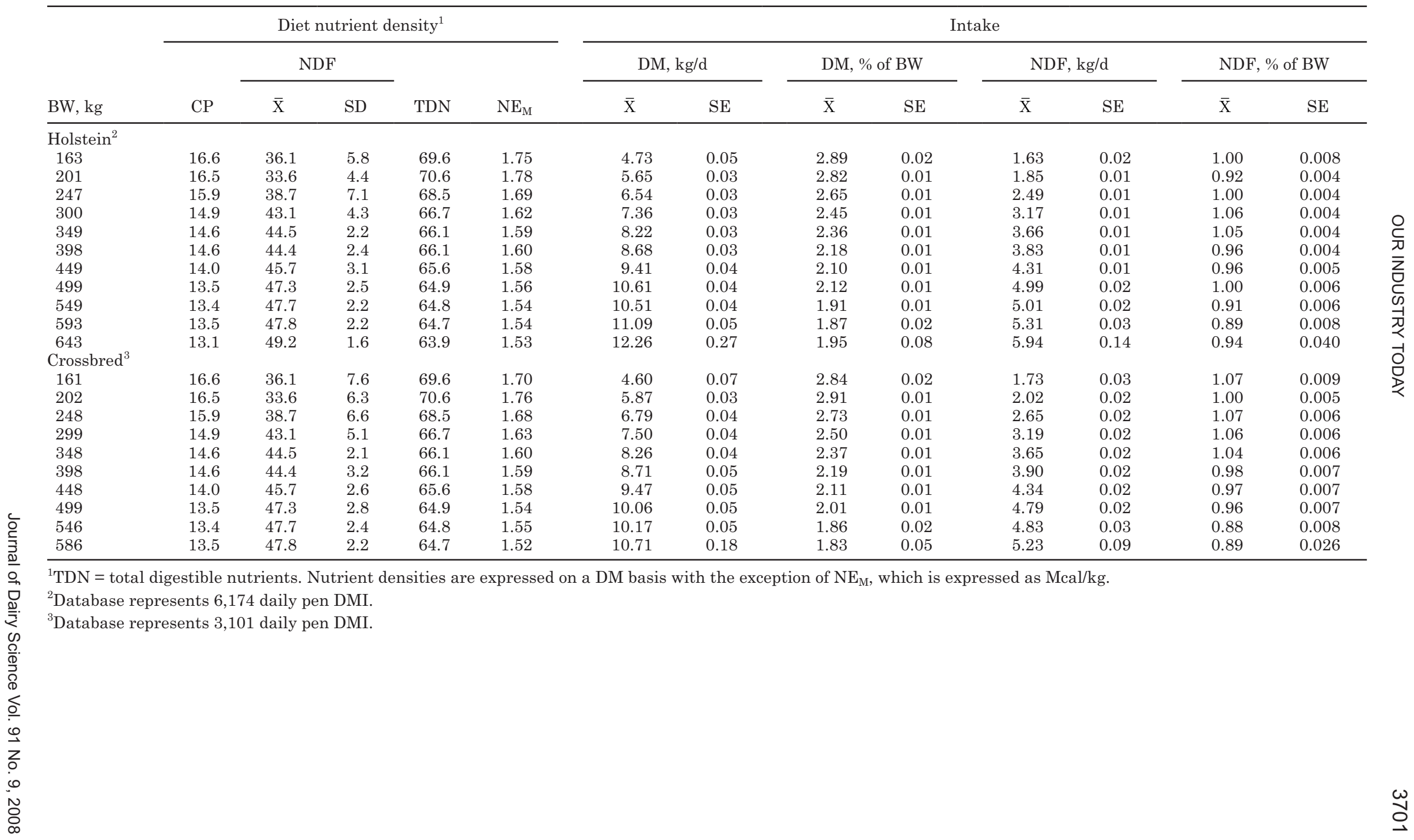


Table 2. Mathematical models to predict DMI of dairy heifers

\begin{tabular}{|c|c|c|c|c|c|c|}
\hline & \multirow[b]{2}{*}{ Model } & \multirow[b]{2}{*}{ Breed } & \multirow[b]{2}{*}{ Model terms ${ }^{2}$} & \multicolumn{2}{|c|}{ Estimate $^{1}$} & \multirow[b]{2}{*}{ DMI equation } \\
\hline & & & & Coefficient & $\mathrm{SE}$ & \\
\hline \multicolumn{7}{|c|}{ iterature DMI equations } \\
\hline \multirow[t]{3}{*}{1} & NRC, 2001 & Holstein/Crossbred & $\mathrm{BW}^{0.75}, \mathrm{~kg}$ & - & - & DMI, $\mathrm{kg} / \mathrm{d}=\left[\mathrm{BW}^{0.75}\left(0.2435 \times \mathrm{NE}_{\mathrm{M}}-0.0466 \times \mathrm{NE}_{\mathrm{M}}^{2}-0.1128\right) / \mathrm{NE}_{\mathrm{M}}\right]$ \\
\hline & & & $\mathrm{NE}_{\mathrm{M}}, \mathrm{Mcal} / \mathrm{kg}$ & - & - & \\
\hline & & & $\mathrm{NE}_{\mathrm{M}}, \mathrm{Mcal} / \mathrm{kg}$ & - & - & $\begin{array}{l}\text { DMI, kg/d }=-29.86+\left(-0.0000154 \times \mathrm{BW}^{2}\right)+\left(0.157 \times \mathrm{BW}^{0.75}\right)+ \\
(2.09 \times \mathrm{ADG})+\left(-0.118 \times \mathrm{ADG}^{2}\right)+(0.73 \times \mathrm{TDN})+(-0.0048 \times\end{array}$ \\
\hline \multirow[t]{5}{*}{2} & Quigley et al., 1986 & Holstein/Crossbred & Intercept & - & - & $\left.\mathrm{TDN}^{2}\right)+(-0.0014 \times \mathrm{BW} \times \mathrm{ADG})+(-0.019 \times \mathrm{TDN} \times \mathrm{ADG})$ \\
\hline & & & $\mathrm{BW}, \mathrm{kg}$ & - & - & \\
\hline & & & $\mathrm{BW}^{0.75}, \mathrm{~kg}$ & - & - & \\
\hline & & & $\mathrm{ADG}, \mathrm{kg} / \mathrm{d}$ & - & - & \\
\hline & & & TDN, \% of DM & - & - & \\
\hline \multicolumn{7}{|c|}{ Alternative DMI equations } \\
\hline 3 & & Holstem & BW, kg & $\begin{array}{l}10.36 \\
-0.0022\end{array}$ & 0.13 & \\
\hline \multirow[t]{2}{*}{4} & Nonlinear & Crossbred & b0 & 12.91 & 0.10 & DMI, $\mathrm{kg} / \mathrm{d}=12.91 \times\left[1-\mathrm{e}^{(-0.00295 \times \mathrm{BW})}\right]$ \\
\hline & & & $\mathrm{BW}, \mathrm{kg}$ & -0.00295 & 0.000042 & \\
\hline \multirow[t]{3}{*}{5} & Nonlinear & Holstein & b0 & 15.79 & 0.13 & DMI, $\mathrm{kg} / \mathrm{d}=15.79 \times\left[1-\mathrm{e}^{(-0.0021 \times \mathrm{BW})}\right]-(0.082 \times \mathrm{NDFdv})$ \\
\hline & & & $\mathrm{BW}, \mathrm{kg}$ & -0.0021 & 0.000027 & \\
\hline & & & NDFdv, \% NDF & 0.082 & 0.0022 & \\
\hline \multirow[t]{3}{*}{6} & Nonlinear & Crossbred & b0 & 13.48 & 0.10 & DMI, $\mathrm{kg} / \mathrm{d}=13.48 \times\left[1-\mathrm{e}^{(-0.0027 \times \mathrm{BW})}\right]-(0.082 \times \mathrm{NDFdv})$ \\
\hline & & & $\mathrm{BW}, \mathrm{kg}$ & -0.0027 & 0.00037 & \\
\hline & & & NDFdv, \% NDF & 0.082 & 0.0028 & \\
\hline \multirow[t]{4}{*}{7} & Mixed & Holstein & Intercept & 2.99 & 0.11 & DMI, $\mathrm{kg} / \mathrm{d}=2.99+(0.0144 \times \mathrm{BW})+(-0.0029 \times \mathrm{T})+(-0.041 \times \mathrm{NDFdv})$ \\
\hline & & & $\mathrm{BW}, \mathrm{kg}$ & 0.0144 & 0.000302 & \\
\hline & & & $\mathrm{T},{ }^{\circ} \mathrm{C}$ & -0.0029 & 0.00076 & \\
\hline & & & NDFdv, \% NDF & -0.041 & 0.0024 & \\
\hline \multirow[t]{4}{*}{8} & Mixed & Crossbred & Intercept & 3.87 & 0.17 & DMI, $\mathrm{kg} / \mathrm{d}=3.87+(0.0118 \times \mathrm{BW})+(-0.0028 \times \mathrm{T})+(-0.035 \times \mathrm{NDFdv})$ \\
\hline & & & $\mathrm{BW}, \mathrm{kg}$ & 0.0118 & 0.000464 & \\
\hline & & & $\mathrm{T},{ }^{\circ} \mathrm{C}$ & -0.0028 & 0.001232 & \\
\hline & & & NDFdv, \% NDF & -0.035 & 0.003884 & \\
\hline
\end{tabular}

${ }^{1}$ Estimates for literature DMI equations were not statistically reevaluated.

${ }^{2} \mathrm{~b} 0=$ maximum assumptive DMI; $\mathrm{T}=$ temperature; $\mathrm{NDFdv}=\mathrm{NDF}$ deviation, where NDFdv $=($ dietary NDF as a $\%$ of $\mathrm{DM})-\left\{[23.11+(0.07968 \times \mathrm{BW})]-\left[0.00006252 \times(\mathrm{BW})^{2}\right]\right\}$; TDN = total digestible nutrients. 
$\left(-0.0000154 \times \mathrm{BW}^{2}\right)+\left(0.157 \times \mathrm{BW}^{0.75}\right)+(2.09 \times \mathrm{ADG})$ $+\left(-0.118 \times \mathrm{ADG}^{2}\right)+(0.73 \times \mathrm{TDN})+\left(-0.0048 \times \mathrm{TDN}^{2}\right)$ $+(-0.0014 \times \mathrm{BW} \times \mathrm{ADG})+(-0.019 \times \mathrm{TDN} \times \mathrm{ADG})$. The mean ADG of the pen of heifers as determined by the aforementioned weighing procedures was used in lieu of individual heifer ADG.

For alternative DMI model equations, variables suitable to use as independent variables to predict dairy heifer DMI were prescreened using the REG procedure of SAS (SAS Institute, Cary, NC) before exploratory model development. The prescreening of independent variable utility was necessary, because many of the potential independent variables to predict heifer DMI are codependent. For example, to meet dairy heifer energy requirements (NRC, 2001), as heifer BW increases, greater NDF diets are fed to decrease dietary energy (i.e., $\mathrm{NE}_{\mathrm{M}}$ ). As a result, dietary $\mathrm{NDF}$ and $\mathrm{NE}_{\mathrm{M}}$ are negatively correlated with each other and logically codependent with BW. This effect is a normal result of formulating ration energy density for dairy heifers (NRC, 2001). Because database diets were formulated to mimic commercial conditions, most dietary ingredients were determined to be correlated with each other and codependent with BW. The effects of breed, BW, $\mathrm{BW}^{0.75}$, ambient $\mathrm{T}$, and their second-order derivatives and interactions were considered as suitable independent variables. Dietary NDF was not considered as a true independent variable, because ration formulation for energy requirements by BW created some codependency with BW. However, because feed energy content is not purely related to NDF (NRC, 2001) and heifer diets were formulated to maintenance and growth energy requirements, substantial variation of dietary NDF among similar BW heifers was present in the data set. A simple scheme was devised to alleviate NDF codependency problems with BW, where the average diet NDF (adNDF) by breed was defined across BW by a second-order equation. The $\mathrm{R}^{2}$ of adNDF equations for Holstein heifers $\{\mathrm{adNDF}, \%$ of DM $=22.07+[0.08714$ $\left.\times \mathrm{BW}]-\left[0.00007383 \times(\mathrm{BW})^{2}\right]\right\}$ and crossbred heifers $\{\mathrm{adNDF}=23.11+[0.07968 \times \mathrm{BW}]-[0.00006252 \times$ $\left.(\mathrm{BW})^{2}\right]$ \} were 0.87 and 0.86 , respectively. Dietary NDF deviation (NDFdv, \% of DM) was then calculated for each heifer pen per day for the 28-mo data collection period as NDFdv, \% of DM = dietary NDF - adNDF.

Alternative DMI prediction model equations were evaluated using first- and second-order random effects mixed models or nonlinear models using the MIXED or NONLIN procedures of SAS (SAS Institute), respectively. Using a mixed linear model, pen was considered as a repeated measured variable, and the correlation between repeated measures was modeled using an autoregressive process. Mixed model evaluations revealed significant $\mathrm{BW} \times$ breed interactions for
DMI; therefore, separate DMI intake equations were developed for Holstein and crossbred heifers. Using the NONLIN procedure, exponential growth curve models were fit to Holstein and crossbred heifer DMI by modified Gauss-Newton methods. The performance of DMI models was assessed by $\mathrm{R}^{2}$, standard errors of prediction, and predicted residual sums of squares (PRESS). To assess potential DMI prediction bias by BW for DMI models, Holstein and crossbred data set were divided into 4 BW quartiles. Prediction residuals (predicted DMI - actual DMI) for each quartile were calculated, mean bias determined, and mean bias was tested whether significantly different than zero (SAS Institute, 1999).

\section{RESULTS}

A summary of diet composition and nutrient intake by BW of Holstein and crossbred heifers used to evaluate published and explore alternative DMI equations for dairy heifers is presented in Table 1 . The number of daily pen DMI observations was 6,174 and 3,101 for Holstein and crossbred heifers, respectively. The BW of heifers ranged from 161 to $643 \mathrm{~kg}$, representing heifers from 4 mo of age until 5 weeks prepartum. Diet nutrient densities were typical of heifer nutrition regimens (NRC, 2001), with diet CP and energy density decreasing and NDF increasing with increasing BW. Dietary NDF, however, varied considerably within each BW with a dietary NDF SD of 7.1 percentage units for 247$\mathrm{kg}$ Holstein heifers and 1.6 percentage units for $643-\mathrm{kg}$ Holstein heifers. Similarly, dietary NDF variation by BW groups was observed in the crossbred DMI data set. Variation in dietary NDF was greater for light heifers as compared with heavier heifers, because maintenance energy requirements of light heifers were more influenced by environment ( $\mathrm{T}$ ) across the 28-mo data collection period (NRC, 2001). As a result, light-weight heifers were commonly fed more dietary energy and potentially less NDF during winter months as compared the to summer months of the data collection period.

Because the NRC (2001) DMI equation for dairy heifers uses $\mathrm{NE}_{\mathrm{M}}$ in the equation, the $\mathrm{NE}_{\mathrm{M}}$ contents of heifer diets are presented in Table 1 and ranged from 1.52 to $1.75 \mathrm{Mcal} / \mathrm{kg}$. Nuances of using $\mathrm{NE}_{\mathrm{M}}$ in NRC (2001) DMI equations for dairy heifers will be discussed later in this manuscript. The DMI of Holstein heifers ranged from 4.73 to $12.26 \mathrm{~kg} / \mathrm{d}$. Maximum DMI of crossbred heifers was numerically lower than that of Holstein heifers, at $10.71 \mathrm{~kg} / \mathrm{d}$, which was the result of crossbred heifers having lighter maximum BW (586 vs. $643 \mathrm{~kg}$ ) as compared with Holstein heifers. Heifer DMI as a percentage of BW decreased with increasing BW for Holstein and crossbred heifers. Intake of NDF in- 
Table 3. Evaluation of mathematical models to predict DMI of dairy heifers

\begin{tabular}{|c|c|c|c|c|c|c|c|c|c|c|}
\hline \multirow[b]{4}{*}{$\mathrm{n}$} & \multirow[b]{4}{*}{ Model } & \multirow[b]{4}{*}{ Model terms ${ }^{3}$} & \multirow[b]{4}{*}{ Breed } & & & & \multicolumn{4}{|c|}{ Holstein DMI prediction bias ${ }^{1}$} \\
\hline & & & & & & & $<275 \mathrm{~kg}$ & 275 to $400 \mathrm{~kg}$ & 400 to $525 \mathrm{~kg}$ & $>525 \mathrm{~kg}$ \\
\hline & & & & \multicolumn{3}{|c|}{ DMI equation performance ${ }^{2}$} & \multicolumn{4}{|c|}{ Crossbred DMI prediction bias } \\
\hline & & & & $\mathrm{R}^{2}$ & $\mathrm{SE}$ & PRESS & $<260 \mathrm{~kg}$ & 260 to $375 \mathrm{~kg}$ & 375 to $490 \mathrm{~kg}$ & $>490 \mathrm{~kg}$ \\
\hline \multicolumn{2}{|c|}{ Literature DMI equations } & & & & & & & $\mathrm{kg}$ & 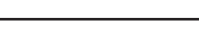 & - \\
\hline \multirow[t]{2}{*}{1} & NRC, 2001 & $\mathrm{BW}^{0.75}, \mathrm{~kg}$ & Holstein & 0.84 & 0.83 & 3,864 & -0.25 & -0.29 & NS & 0.48 \\
\hline & & $\begin{array}{l}\mathrm{NE}_{\mathrm{M}}, \mathrm{Mcal} / \mathrm{kg} \\
\mathrm{NE}_{\mathrm{M}}, \mathrm{Mcal} / \mathrm{kg}\end{array}$ & Crossbred & 0.84 & 0.86 & 1,592 & -0.73 & -0.28 & NS & 0.70 \\
\hline \multirow[t]{2}{*}{2} & Quigley et al., 1986 & Intercept & Holstein & 0.84 & 0.80 & 3,966 & NS & 0.29 & -0.14 & -0.46 \\
\hline & & $\begin{array}{l}\mathrm{BW}, \mathrm{kg} \\
\mathrm{BW}^{0.75}, \mathrm{~kg} \\
\mathrm{ADG}, \mathrm{kg} / \mathrm{d} \\
\mathrm{TDN}, \% \text { of } \mathrm{DM}\end{array}$ & Crossbred & 0.85 & 0.69 & 1,454 & -0.26 & 0.15 & NS & -0.13 \\
\hline \multicolumn{2}{|c|}{ Alternative DMI equations } & & & & & & & & & \\
\hline 3 & Nonlinear & $\begin{array}{l}\text { b0 } \\
\text { BW, kg }\end{array}$ & Holstein & 0.86 & 0.73 & 3,325 & -0.17 & 0.18 & NS & NS \\
\hline 4 & Nonlinear & b0 & Crossbred & 0.84 & 0.81 & 4,047 & -0.14 & 0.17 & NS & NS \\
\hline 5 & Nonlinear & $\begin{array}{l}\text { b0 } \\
\text { BW, kg } \\
\text { NDFdv, \% NDF }\end{array}$ & Holstein & 0.84 & 0.71 & 1,584 & NS & NS & NS & NS \\
\hline 6 & Nonlinear & $\begin{array}{l}\text { b0 } \\
\text { BW, kg } \\
\text { NDFdv, \% NDF }\end{array}$ & Crossbred & 0.87 & 0.60 & 1,115 & NS & NS & NS & NS \\
\hline 7 & Mixed & $\begin{array}{l}\text { Intercept } \\
\text { BW, kg } \\
\text { T, }{ }^{\circ} \mathrm{C} \\
\text { NDFdv, \% NDF }\end{array}$ & Holstein & 0.86 & 0.66 & 2,683 & 0.12 & NS & -0.22 & 0.16 \\
\hline \multirow[t]{4}{*}{8} & Mixed & Intercept & Crossbred & 0.85 & 0.67 & 1,405 & 0.26 & NS & -0.36 & NS \\
\hline & & $\mathrm{BW}, \mathrm{kg}$ & & & & & & & & \\
\hline & & $\mathrm{T},{ }^{\circ} \mathrm{C}$ & & & & & & & & \\
\hline & & NDFdv, \% NDF & & & & & & & & \\
\hline
\end{tabular}

${ }^{1}$ DMI bias (predicted DMI - actual DMI) by BW quartile. DMI prediction bias is not significantly different than 0.

${ }^{2}$ PRESS $=$ predicted residual sums of squares.

${ }^{3} \mathrm{~b} 0=$ maximum assumptive DMI, $\mathrm{T}=$ temperature; NDFdv $=\mathrm{NDF}$ deviation, where NDFdv $=($ dietary NDF as a $\%$ of DM $)-\left\{[23.11+(0.07968 \times \mathrm{BW})]-\left[0.00006252 \times(\mathrm{BW})^{2}\right]\right\}$; TDN $=$ total digestible nutrients. 
creased with increasing BW, but NDF intake as a percentage of BW was relatively static at approximately $1.0 \%$ of BW in Holstein and crossbred heifers weighing $<500 \mathrm{~kg}$. At BW $>500 \mathrm{~kg}$, NDF intake as a percentage of BW declined slightly.

It was not the intent of this study to evaluate regulation of DMI in dairy heifers, but NDF intake observations are of special interest, because they potentially conform to gut fill theories (Mertens, 1994) of intake regulation. Mertens (1994) suggested that gut fill regulation of DMI occurs in lactating dairy cows at $1.2 \%$ of BW when lactating cows are fed diets containing $>30 \%$ NDF. Diets fed to heifers (Table 1) ranged from 36.1 to $49.2 \% \mathrm{NDF}$, which are greater in NDF than diets typically fed to lactating dairy cows. Data suggest that NDF gut fill regulation may occur near $1.0 \%$ of $\mathrm{BW}$ in heifers, as compared with $1.2 \%$ of BW for lactating dairy cows; however, this study does not provide conclusive evidence, and more exacting studies are warranted.

The decline in NDF intake as a percentage of BW below $1.0 \%$ for heifers weighing $>500 \mathrm{~kg}$ may be related to declining gut capacity due to volume displacement by the developing fetus. Ideally, the influence of gestation length on heifer DMI should have been explored, but all data were pen-based and correspondingly would have required calculation of average gestation length per pen to do so. Because heifers individually left the IDRF 4 to 6 wk before their projected calving date, we could not resolve whether average pen gestation length was a true measure of the effects of pregnancy on DMI; thus, inclusion of gestation length in DMI models was not attempted.

Mathematical models to predict DMI in dairy heifers are presented in Table 2 and include Quigley et al. (1986), NRC (2001), and estimates for 6 alterative models. Statistical evaluation of these models to predict DMI of dairy heifers is presented in Table 3. Because breed $\times$ BW interactions $(P<0.01)$ for DMI intake were observed in REG screening and in MIXED procedures, separate DMI models are presented for Holstein and crossbred heifers. Breed $\times$ BW interactions for DMI would be expected, because Holstein and crossbred heifers differ in mature size potential and therefore would have dissimilar chemical composition and metabolic efficiency at similar BW (NRC, 1996). There are some differences in Holstein and crossbred DMI models presented in Table 3 , but, practically, the DMI models are similar. Having 2 breeds to develop DMI models was advantageous to observe and validate model functionality, but due to their similarity, minimal discussion will be devoted to the effects of breed on heifer DMI.

The NRC (2001) equation (model 1) predicted DMI of Holstein and crossbred heifers with reasonable accu- racy $\left(\mathrm{R}^{2}=0.84\right)$, with standard errors of predictions of 0.83 and $0.86 \mathrm{~kg} / \mathrm{d}$ for Holstein and crossbred heifers, respectively. Some concerns with predicting DMI of dairy heifers using model 1 were observed as reflected by significant $(P<0.001)$ DMI by BW prediction biases (Table 3). Model 1 (NRC, 2001) underpredicted DMI of light Holstein heifers $(<275)$ and crossbred heifers $(<260 \mathrm{~kg}) 0.25$ and $0.73 \mathrm{~kg} / \mathrm{d}$, respectively. Conversely, DMI of heavy Holstein $(>525 \mathrm{~kg})$ and crossbred heifers $(>490 \mathrm{~kg})$ was significantly $(P<0.001)$ overpredicted by model 1 . Dry matter intake prediction bias associated with the NRC (2001) heifer DMI equation may be partially explained by some nuances of the NRC (2001) DMI equation. First, the NRC (2001) DMI equation utilizes $\mathrm{NE}_{\mathrm{M}}$ as an independent variable in the equation. In dairy heifer diets, dietary $\mathrm{NE}_{\mathrm{M}}$ is not highly variable, because dairy heifers are fed primarily forage. Dietary $\mathrm{NE}_{\mathrm{M}}$ content of diets (Holstein and crossbred) in this study ranged from 1.52 to $1.75 \mathrm{Mcal} / \mathrm{kg}$. When the range of $\mathrm{NE}_{\mathrm{M}}(0.23 \mathrm{Mcal} / \mathrm{kg})$ was applied to the NRC (2001) DMI equation, predicted DMI changed by only $0.05 \mathrm{~kg} / \mathrm{d}$. Second, in dairy heifer nutrition programs, dietary $\mathrm{NE}_{\mathrm{M}}$ typically decreases with increasing $\mathrm{BW}$ (MPS, 2003). The result is that dietary $\mathrm{NE}_{\mathrm{M}}$ can be codependent with BW, as was the case in the Holstein and crossbred data sets used in this study (Table 1). When the NRC (2001) equation is used to predict DMI of dairy heifers across a broad range of heifer BW for dairy heifers fed near NRC (2001) guidelines, the equation performs more or less as a linear equation, because metabolic BW $\left(\mathbf{B W}^{0.75}\right)$ primarily influences DMI prediction. Because the NRC (2001) DMI equation is nearly linear helps explain why prediction biases occur at the BW endpoints of the equation. Quigley et al. (1986) reported that dairy heifer DMI was better defined by second-order models containing BW or dietary factors, as compared with linear models.

Performance statistics of predicting heifer DMI by Quigley et al. (1986; model 2) are also presented in Table 3. The $\mathrm{R}^{2}$ and standard errors of DMI prediction were similar when heifer DMI was predicted by Quigley et al. (1986) as compared with NRC (2001). The PRESS statistic for Holsteins using model 1 and model 2 was also similar (3,864 vs. 3,966$)$, suggesting that similar amounts of variance in DMI were unaccounted for by both equations. Similar PRESS statistics were also observed for crossbred DMI (1,592 vs. 1,454) as predicted by models 1 and 2 . Similar to the NRC (2001), predicting heifer DMI by the equation of Quigley et al. (1986) resulted in significant $(P<0.001)$ prediction biases for light and heavy heifers. The DMI of Holstein heifers $>525 \mathrm{~kg}$ was underpredicted by $0.46 \mathrm{~kg} / \mathrm{d}$ by model 2 . Model 2 also underpredicted the DMI of crossbred heifers $<260 \mathrm{~kg}$ by $0.26 \mathrm{~kg} / \mathrm{d}$. 
Alternative exponential or mixed models were explored in an attempt to remediate minor DMI prediction issues observed with Quigley et al. (1986) and NRC (2001) equations. Alternative models to predict DMI of dairy heifers are likewise presented in Table 3. A simple set of exponential DMI models (model 3 and 4) containing a single term (BW) were explored for comparative purposes, because, as explained above, $\mathrm{BW}^{0.75}$ has the primary influence on DMI predicted by NRC (2001). Using $\mathrm{BW}^{0.75}$ and $\mathrm{BW}$ in exponential models was explored, but no appreciable difference in utility was found, so BW was used for simplicity.

Exponential models 3 and 4 predicted DMI of Holstein and crossbred heifers with similar relative efficiency $\left(R^{2}=0.84\right)$ as the NRC (2001) equation with standard errors of DMI prediction of 0.71 and 0.81 $\mathrm{kg} / \mathrm{d}$ for Holstein and crossbred heifers, respectively. Model 3 modestly decreased the PRESS statistic (3,325 vs. 3,864) for prediction of Holstein DMI as compared with the NRC (2001); however, model 4 substantially increased the PRESS statistic $(4,027$ vs. 1,592$)$ for crossbred heifer DMI prediction. Data suggest precision of predicting heifer DMI using an exponential model with a single BW term was no more or no less precise than predicting heifer DMI with established equations (Quigley et al., 1986; NRC, 2001). Using an exponential model, however, decreased DMI prediction biases. No DMI prediction biases were observed when heifer DMI was predicted using models 3 or 4 for heavy Holstein $(>525 \mathrm{~kg})$ or crossbred $(>409 \mathrm{~kg})$ heifers. Models 3 and 4 underpredicted DMI of light-weight Holstein $(<275$ $\mathrm{kg})$ and crossbred $(<260 \mathrm{~kg})$ by 0.17 and $0.14 \mathrm{~kg} / \mathrm{d}$ but underpredictions were lower as compared with DMI underprediction by models 1 and 2 .

For alternative models 5 and 6 , a dietary term (NDFdv) was added to models 3 and 4 in an attempt to improve the precision of heifer DMI prediction. Adding $\mathrm{NDFdv}$ to exponential models resulted in modest increases in $\mathrm{R}^{2}$ and decreases in standard errors of heifer DMI predictions, as compared with models $1,2,3$, and 4. Adding NDFdv to models 3 and 4 (models 5 and 6) decreased PRESS as compared with models 1, 2, 3, and 4 , indicating a sizeable source of variance in DMI was accounted for. In addition, using an exponential model with NDFdv resulted in mitigation of DMI prediction biases for both Holstein and crossbred heifers (Table 3).

Inclusion of NDFdv in a DMI equation is novel, but it is presented as a concept to better understand how DMI prediction of dairy heifers could be improved. For example, for 300-kg heifers, the adNDF equation $\{22.07$ $\left.+[0.08714 \times \mathrm{BW}]-\left[0.00007383 \times(\mathrm{BW})^{2}\right]\right\}$ calculates the average NDF (43.1\% of DM) fed to $300-\mathrm{kg}$ heifers in the data set (Table 1). If a pen of 300-kg heifers was fed a diet containing $34.5 \%$ (-2 SD) NDF, the NDFdv would be $-8.6 \%$. For each percentage unit of NDF fed above or below the adNDF, DMI decreases or increases, respectively, $0.082 \mathrm{~kg} / \mathrm{d}$. For the example above, DMI of $300-\mathrm{kg}$ heifers fed $34.5 \% \mathrm{NDF}$ would be estimated to be $0.71 \mathrm{~kg}$ greater than $300-\mathrm{kg}$ heifers fed $43.1 \% \mathrm{NDF}$. Although the concept is rudimentary, inclusion of NDFdv (models 5 and 6) in a heifer DMI equation markedly decreased the PRESS statistic and prediction bias, as compared with DMI equations based on BW alone (models 3 and 4), indicating improved precision of DMI predictions. The approach is supported by Tomlinson et al. (1991), who observed that DMI of 180- and 270-kg dairy heifers was increased or decreased $0.05 \mathrm{~kg}$ for each percentage unit change in dietary NDF. Based on these observations and the observations of Tomlinson et al. (1991), some method of accounting for the influence of dietary NDF in heifer DMI equations has the potential to improve DMI prediction of dairy heifers.

These observations are visually presented in Figure 1. Dry matter intake prediction (predicted DMI - actual DMI, kg/d) residuals were plotted by heifer BW for models 1, 2, 3, and 5 (Holstein heifers). The observed underprediction of DMI for light heifers and overprediction of DMI for heavy heifers can be visually seen for model 1 (NRC, 2001). Similarly, underprediction of DMI of heavy heifers when predicted by model 2 (Quigley et al., 1986) is evident. Using an exponential model (model 3) decreases DMI prediction bias of both light and heavy heifers, and adding NDFdv to an exponential model (model 5) increased DMI prediction precision especially for heifers $<300 \mathrm{~kg}$, which is logical, because dietary NDFdv was the greatest for heifers $<300 \mathrm{~kg}$ (Table 1).

Dry matter intake prediction models 7 and 8 were developed using mixed models with significant effects of BW, T, and NDFdv retained in the models. Although the effect of T on DMI was significant $(P<0.03)$ in mixed models 7 and 8, its overall effect on DMI as compared with BW or NDFdv was small. Model 7 and 8 yielded $\mathrm{R}^{2}$ values of 0.86 and 0.85 and standard errors of prediction of 0.66 and $0.67 \mathrm{~kg} / \mathrm{d}$ for Holstein and crossbred heifers, respectively. Mixed models (models 7 and 8) did improve DMI prediction precision as compared with models 1 and 2, but PRESS statistics were greater as compared with exponential models 5 and 6 , indicating an increase in unaccounted variance. In addition, significant $(P<0.001)$ prediction biases were observed for both light- and heavy-weight heifers. Data suggest although improvements in heifer DMI prediction could be made using mixed models, exponential models were moderately more precise. 

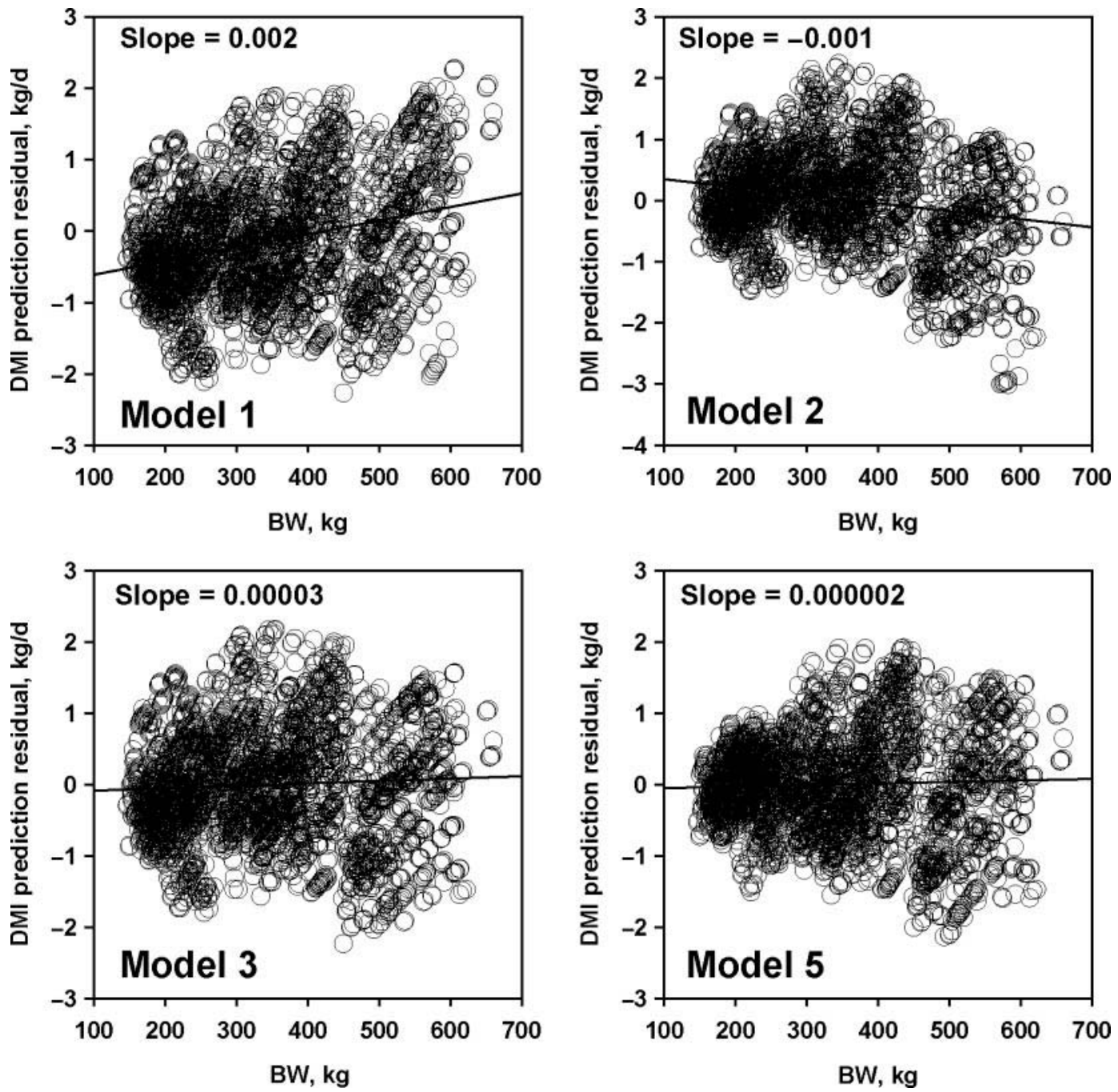

Figure 1. Dry matter intake prediction residuals (predicted DMI-actual DMI, kg) of Holstein heifers when DMI is predicted by model 1 where: DMI, $\mathrm{kg} / \mathrm{d}=\left[\mathrm{BW}^{0.75}\left(0.2435 \times \mathrm{NE}_{\mathrm{M}}-0.0466 \times \mathrm{NE}_{\mathrm{M}}{ }^{2}-0.1128\right) / \mathrm{NE}_{\mathrm{M}}\right]$, model 2 where: $\mathrm{DMI}, \mathrm{kg} / \mathrm{d}=-29.86+\left(-0.0000154 \times \mathrm{BW}^{2}\right)+(0.157$ $\left.\times \mathrm{BW}^{0.75}\right)+(2.09 \times \mathrm{ADG})+\left(-0.118 \times \mathrm{ADG}^{2}\right)+(0.73 \times \mathrm{TDN})+\left(-0.0048 \times \mathrm{TDN}^{2}\right)+(-0.0014 \times \mathrm{BW} \times \mathrm{ADG})+(-0.019 \times \mathrm{TDN} \times \mathrm{ADG})$, model 3 where: DMI, kg/d $=15.36 \times\left[1-\mathrm{e}^{(-0.0022 \times \mathrm{BW})}\right]$, and model 5 where: DMI, kg/d $=15.79 \times\left[1-\mathrm{e}^{(-0.0021 \times \mathrm{BW})}\right]-(0.082 \times \mathrm{NDFdv})$. Neutral detergent fiber deviation $(\mathrm{NDF} d v)=($ dietary NDF as a $\%$ of DM $)-\left\{23.11+[0.07968 \times \mathrm{BW}]-\left[0.00006252 \times(\mathrm{BW})^{2}\right]\right\} ;$ TDN $=$ total digestible nutrients

\section{DISCUSSION}

The primary objective of this project was to evaluate previously published (Quigley et al., 1986; NRC, 2001) DMI intake equations for dairy heifers and explore whether DMI equations for dairy heifers could be improved. Our evaluation suggest previously published DMI equations are reasonable to predict DMI of heifers, but both equations result in prediction biases for light and heavy heifers. Using exponential models to predict heifer DMI with or without NDFdv helped remediate DMI prediction biases.

The DMI equation of Quigley et al. (1986) does not have widespread use because NRC (2001) adopted the beef heifer DMI equation (NRC, 1996). The equation was adopted by NRC (2001) because large, robust data sets of dairy heifer DMI were not available at the time of review. The adoption of this equation (NRC, 2001) for dairy heifers resulted in a disconnection between the DMI predictions for heifers and the DMI predictions adopted by the NRC (2001) for prepartum transition heifers (Hayirli et al. 1998, 2003). Disconnect of DMI prediction for heifers and DMI prediction of prepartum transition heifers was resolved by NRC (2001) by the addition of an adjustment factor that was not validated.

The continuity between predicted DMI for dairy heifers using the NRC (2001) DMI equation, a exponential equation (model 3), the transition heifer DMI equation adopted by the NRC (2001), and NRC 


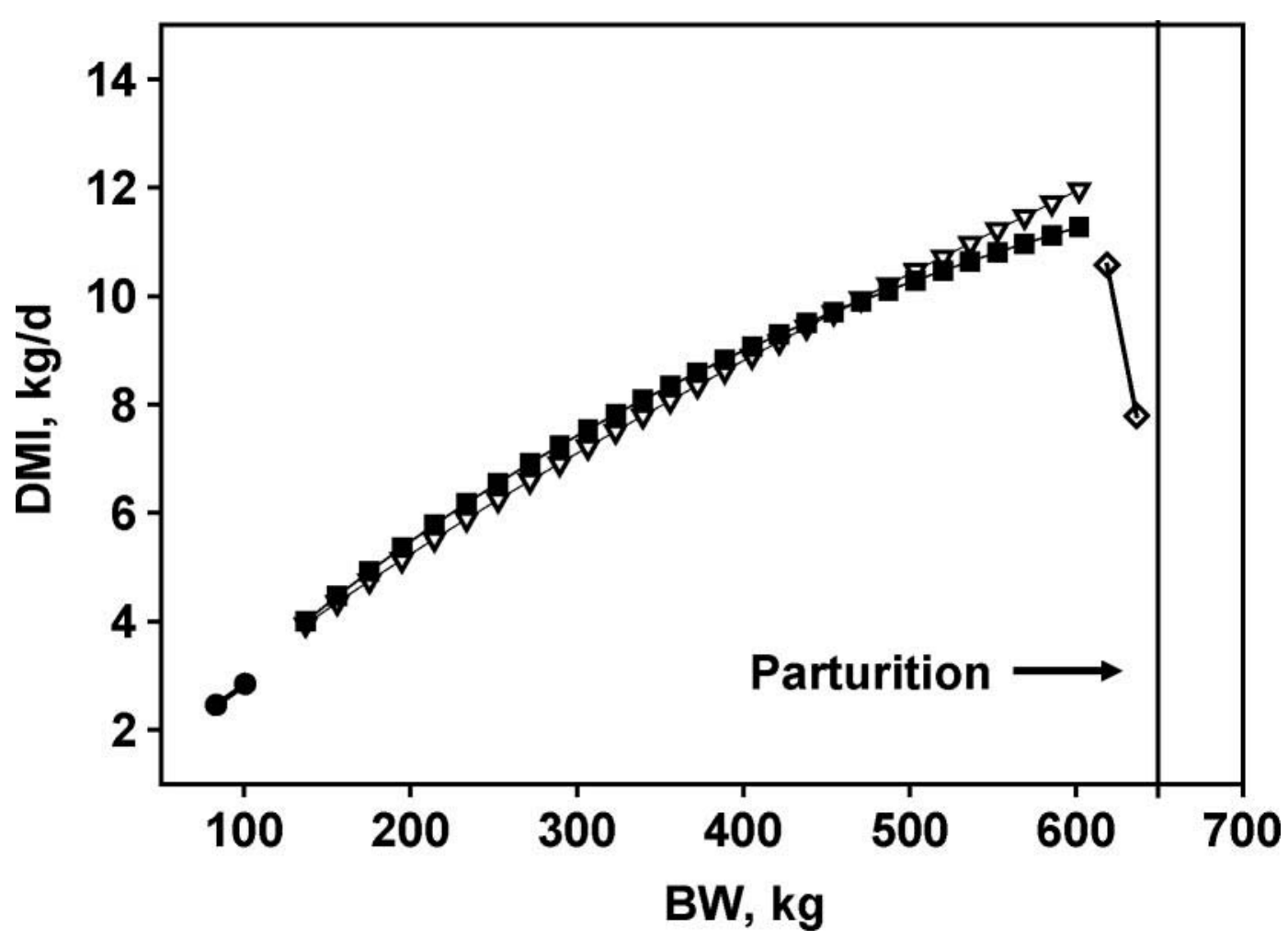

Figure 2. Continuity of heifer DMI predictions as predicted by the heifer DMI equation of NRC (2001) ( $\Delta$ ), a negative exponential model where DMI, $\mathrm{kg} / \mathrm{d}=15.38 \times\left[1-\mathrm{e}^{(0.0022 \times \mathrm{BW})}\right](\mathbf{\bullet})$, NRC, 2001 transition heifer DMI equation $(\diamond)$, or NRC (2001) tabular DMI of postweaned heifers $(\bullet)$

(2001) tabular postweaning heifer DMI is presented in Figure 2. For a Holstein heifer weighing $625 \mathrm{~kg}$ at $21 \mathrm{~d}$ prepartum (MPS, 2003), the late gestation DMI equation of Hayirli et al. $(1998,2003)$ as adopted by NRC (2001) predicts $1.5 \mathrm{~kg} / \mathrm{d}$ less DMI for transition heifers as compared with the NRC (2001) heifer DMI equation. Using exponential model 3 to predict heifer DMI based on BW alone narrows the disconnection between transition heifer DMI predictions and heifer DMI predictions to less than $0.5 \mathrm{~kg} / \mathrm{d}$. Tabular values (NRC, 2001) of postweaning heifers $(100 \mathrm{~kg})$ were also plotted on Figure 2 to assess possible light-weight heifer discrepancies in DMI prediction. Although no mathematical inferences could be made due to the lack of a postweaning heifer DMI data set, both the NRC (2001) DMI equation and exponential model 3 equation appear to yield reasonable fits to NRC (2001) DMI of postweaning heifers. Using exponential models to predict dairy heifer DMI appears to yield predictions that are continuous to NRC (2001) postweaning heifer DMI and modestly improves continuity between NRC (2001) transition heifer DMI prediction, as compared with the NRC (2001) heifer DMI prediction. Because there are only minor differences in exponential models 4 to 6 , as compared with model 3 , these data are not shown, but these models yielded similar results.

\section{CONCLUSIONS}

In conclusion, previously published DMI equations (Quigley et al., 1986; NRC, 2001) predicted DMI of dairy heifers reasonably well, but both equations over- or underpredict DMI of light or heavy heifers. Employing exponential models to predict DMI of dairy heifers modestly improved DMI prediction, decreased DMI prediction biases, and decreased the disconnect between dairy heifer DMI predictions and predictions of DMI for transition heifers (NRC, 2001; Hayirli et al., 1998, 2003). Including dietary NDFdv in a heifer DMI equation (models 5 and 6 ) has the potential to further increase the precision of DMI prediction for dairy heifers.

\section{ACKNOWLEDGMENTS}

This project was supported by National Research Initiative Grant no. 2004-35205-14210 from the USDA 
Cooperative State Research, Education, and Extension Service.

\section{REFERENCES}

AOAC. 1990. Official Methods of Analysis. 15th ed. AOAC, Arlington, VA.

Goering, H. K., and P. J. Van Soest. 1970. Pages 8-11 in Forage Fiber Analyses (Apparatus, Reagents, Procedures, and Some Applications). Agric. Handbook No. 379. ARS-USDA, Washington, DC.

Hayirli, A., R. R. Grummer, E. V. Nordheim, and P. M. Crump. 2003. Models for predicting dry matter intake of Holsteins during the prefresh transition period. J. Dairy Sci. 86:1771-1779.

Hayirli, A., R. R. Grummer, E. V. Nordheim, P. Crump, D. K. Beede, M. J. VandeHaar, and L. M. Kilmer. 1998. A mathematical model for describing dry matter intake of transition cows. J. Dairy Sci. 81(Suppl. 1.):296. (Abstr.)

Maltecca, C., H. Khatib, V. R. Schutzkus, P. C. Hoffman, and K. A. Weigel. 2006. Changes in conception rate, calving performance, and calf health and survival from the use of crossbred Jersey $\times$ Holstein sires as mates for Holstein dams. J. Dairy Sci. 89:2747-2754.

Mertens, D. R. 1992. Critical conditions in determining detergent fibers. Page C-1 in Proc. Natl. Forage Test. Assoc. Forage Anal. Workshop, Denver, CO. Natl. Forage Test. Assoc., Omaha, NE.

Mertens, D. R. 1994. Regulation of forage intake. Page 450 in Forage Quality and Utilization. Am., Soc. Agron. Madison, WI.

MPS. 2003. Raising Dairy Replacements. Midwest Plan Serv., Ames, IA.

NRC. 1996. Nutrient Requirements of Beef Cattle. 7th rev ed. Natl. Acad. Sci., Washington, DC.

NRC. 2001. Nutrient Requirements for Dairy Cattle. 7th rev. ed. Natl. Acad. Sci., Washington, DC.

Quigley, J. III, R. E. James, and M. L. McGilliard. 1986. Dry matter intake in dairy heifers. 2. Equations to predict intake of heifers under intensive management. J. Dairy Sci. 69:2863-2867.

SAS Institute. 1999. SAS User's Guide: Statistics. Version 8 ed. SAS Inst. Inc., Cary, NC.

Tomlinson, D. J., R. E. James, and M. L. McGilliard. 1991. Effect of varying levels of neutral detergent fiber and total digestible nutrients on intake and growth of Holstein heifers. J. Dairy Sci. $74: 537-545$. 